\title{
Minimálisan invazív, endoszkóppal asszisztált, transcribriform reszekció a koponyaalap rosszindulatú daganatainak sebészetében
}

\author{
Piski Zalán dr. ${ }^{1}$ - Büki András dr. ${ }^{2}$ - Gerlinger Imre dr. ${ }^{1}$ \\ Tóth István dr. ${ }^{1}$ - Nepp Nelli dr. ${ }^{1}$ - Lujber László dr. ${ }^{1}$ \\ ${ }^{1}$ Pécsi Tudományegyetem, Általános Orvostudományi Kar, Klinikai Központ, \\ Fül-Orr-Gégészeti és Fej-, Nyaksebészeti Klinika, Pécs \\ ${ }^{2}$ Pécsi Tudományegyetem, Általános Orvostudományi Kar, Klinikai Központ, Idegsebészeti Klinika, Pécs
}

\begin{abstract}
Bevezetés: A koponyaalapot is érintő rosszindulatú sinonasalis daganatok legtöbb típusa sebészi ellátást tesz szükségessé. Az esetek nagy részében ma már lehetôség nyílik minimálisan invazív, craniofacialis külső feltárás nélküli, endoszkópos mútétet végezni.

Célkitüzés: Közleményünkben a koponyaalapot destruáló rosszindulatú daganatok sebészi megoldása céljából alkalmazott endoszkópos transcribriform feltárással szerzett tapasztalatainkról számolunk be.

Módszer: 2015. február és 2017. július között négy férfi és 1 nőbetegen hajtottunk végre mútétet. Az átlagéletkor 64,6 év volt (59-70, medián: 66). Minden mútét az orrüregen keresztül, minimálisan invazív behatolással, endoszkópos vizualizáció mellett történt, a koponyaalap transcribriform feltárásával és reszekciójával. A mútét indikációját 2 esetben Kadish szerinti C-stádiumú esthesioneuroblastoma, l esetben T3N0 sinonasalis nem differenciált carcinoma, l esetben T1N0 intestinalis típusú adenocarcinoma, illetve további l esetben T4N0-laphámcarcinoma képezte. Eredmények: A betegek követési ideje 14 és 46 hónap között alakult, átlagosan 22,8 hónap volt. A mútétek során intraoperatív szövődmény nem lépett fel. A posztoperatív időszakban egy beteg esetében liquorrhoea, illetve emellett pneumocephalus alakult ki, melyek lumbalis drenázs alkalmazása és konzervatív kezelés mellett rendeződtek. Az utánkövetés során egyik beteg esetében sem észleltünk recidívát.

Következtetés: Az elülső koponyaalap rosszindulatú daganatainak sebészi megoldásaként az endoszkópos, transnasalis, transcribriform feltárással végzett reszekció kiváló alternatívája a külső feltárásból végzett mútéteknek a biztonságos kivitelezhetőség és a megfelelő onkológiai eredmény elérésének szempontjából is.
\end{abstract}

Orv Hetil. 2019; 160(40): 1584-1590.

Kulcsszavak: craniofacialis reszekció, endoszkóp, koponyaalap, tumor

\section{Minimally invasive endoscopic transcribriform resection of malignant lesions of the skull base}

Introduction: Malignant tumours of the sinonasal region - including those with invasion of the skull base - necessitate surgical resection. The majority of the cases give an opportunity to perform the procedure via minimally invasive, endoscopic approach, without external, craniofacial surgery.

Aim: To assess our clinical experience in treating anterior skull base malignancies, performing minimally invasive endoscopic transcribriform resection.

Method: Between February 2015 and July 2017, four male and one female patient underwent minimally invasive, endoscopic skull base procedure. The mean age was 64.6 years (59-70, median: 66). Every surgery was performed via transnasal, endoscopic transcribriform approach. In two cases Kadish C esthesioneuroblastomas, while in one case a T3N0 sinonasal non-differentiated carcinoma, a T1N0 intestinal type adenocarcinoma and a T4N0 squamous cell carcinoma was the indication of surgery, respectively.

Results: The mean follow-up time was 22.8 months, between 14 and 46 months. Intraoperative complications did not occur during the procedures. Regarding the postoperative period, liquorrhoea and pneumocephalus occurred in one case. Complications were solved with lumbar drainage. During follow-up, neither residual nor recurrent tumour was observed in our patients. 
Conclusion: Endoscopic transcribriform resection of the skull base malignancies is a safe and viable alternative to the traditional open approach.

Keywords: craniofacial resection, endoscope, skull base, tumour

Piski Z, Büki A, Gerlinger I, Tóth I, Nepp N, Lujber L. [Minimally invasive endoscopic transcribriform resection of malignant lesions of the skull base]. Orv Hetil. 2019; 160(40): 1584-1590.

(Beérkezett: 2019. március 5.; elfogadva: 2019. április 19.)

\section{Rövidítések}

$4 \mathrm{~K}=4000$ pixeles vízszintes felbontás, $\mathrm{K}$ mint 'kilo' (az ezres szám rövidített formája); CT = (computed tomography) számítógépes tomográfia; HD = (high-density) nagy felbontású; $\mathrm{MR}=($ magnetic resonance $)$ mágneses rezonancia

Az elülső koponyaalapot érintő rosszindulatú daganatos folyamatok mútéti megoldása komoly kihívást jelent a klinikus számára. Ez a régió két sebészi szakma, az idegsebészet és a fül-orr-gégészet - anatómiáját tekintve rendkívül bonyolult - határterülete. Emellett a sinonasalis daganatok - melyek a leggyakrabban tehetők felelőssé a koponyaalap destrukciójáért - rendkívül ritka tumorok. A sinonasalis tumorok az összes fej-nyaki daganat mindössze 3\%-át adják [1], így kezelésükkel kapcsolatban még a nagy forgalmú centrumokban is rendkívül nehezen gyưlik össze elégséges tapasztalat. A scala anterior környezete közvetlenül határos az orr- és orrmelléküregekkel, így az itt kialakuló kórfolyamatok megközelítéséhez korábban a fül-orr-gégészeti transfacialis, esetleg szájpitvari és az idegsebészeti frontális transcranialis behatolás kombinációjára volt szükség. Ez az először Ketcham és $m t s a i$ által ismertetett craniofacialis feltárás, mely szerencsés esetben a két szakterület együttmúködésével végzett operáció során valósul meg [2]. A beavatkozás kiterjedt, külső, az arc bőrén keresztül történő feltárást igényel, melynek morbiditása az irodalmi adatok szerint a 36\%-ot is elérheti, igen magas, 5\%-os mortalitás mellett [3]. A fül-orr-gégészeti endoszkópos beavatkozásoknak az utóbbi évtizedekben lezajlott intenzív fejlődése a koponyaalap sebészetére is nagy hatással volt. A fül-orr-gégészetben több mint harminc éve alkalmaznak minimálisan invazív, tisztán endoszkópos behatolást az orr és az orrmelléküregek gyulladásos és daganatos folyamatai esetén is [4]. Észszerünek tûnt tehát, hogy a kellő tapasztalat megszerzését követően a koponyaalapot érintő malignus térfoglalások eltávolítása is elképzelhető a minimálisan invazív endoszkópos technika alkalmazásával. A koponyaalapot érintő daganatokhoz különböző sebészi feltárások kivitelezhetők, melyek a tumor elhelyezkedésének függvényében kombináltan is alkalmazhatók. Ilyen a fossa olfactoria folyamataiban alkalmazható „transcribriform”, a planum sphenoidale reszekciójával járó „transplanum" és a clivus vagy akár az agytörzs térfoglalásai- hoz vezető „transclivalis” feltárás. A koponyaalap laterális aspektusainak elérését teszi lehetővé a transpterygoidealis és a „transorbitalis” feltárás, bár az utóbbi már nem tartozik az orrüregen keresztül kivitelezett beavatkozásokhoz. Bár bizonyos esetekben a tumor elhelyezkedése ma is külső feltárásból végzett mútétre kényszerítheti az operatőrt, a nemzetközi irodalom egységesnek látszik abban a tekintetben, hogy ha adottak a feltételei a minimálisan invazív endoszkópos beavatkozásnak, akkor külső feltárás nélkül kell elvégezni a tumorreszekciót [512]. Jelen közleményünkben a koponyaalapot destruáló rosszindulatú daganatok sebészi megoldása céljából alkalmazott endoszkópos transcribriform feltárással szerzett tapasztalatainkat mutatjuk be.

\section{Módszer}

2015. február és 2017. július között a Pécsi Tudományegyetem Klinikai Központja Idegsebészeti, illetve FülOrr-Gégészeti és Fej-, Nyaksebészeti Klinikájának együttmúködésével 4 férfi és 1 nőbetegen hajtottunk végre mútétet (1. táblázat). Az átlagéletkor 64,6 év volt (59-70, medián: 66). Minden mütét az orrüregen keresztül, minimálisan invazív behatolással, endoszkópos vizualizáció mellett történt, a koponyaalap transcribriform feltárásával és reszekciójával. A mütét indikációját 2 esetben esthesioneuroblastoma, 1 esetben sinonasalis

\begin{tabular}{|c|c|c|c|c|}
\hline \multicolumn{2}{|c|}{ 1. táblázat } & \multicolumn{2}{|l|}{$\begin{array}{l}\text { Transcribriform } \\
\text { adatai }\end{array}$} & átesett betegeink \\
\hline Beteg & $\begin{array}{l}\text { Kor } \\
\text { (év) }\end{array}$ & Szövettan & $\begin{array}{l}\text { A tumor } \\
\text { kiterjedése } \\
\text { (stádium) }\end{array}$ & $\begin{array}{l}\text { Preoperatív } \\
\text { kezelés }\end{array}$ \\
\hline Sz. S. & 66 & ENB & Kadish C & Nem \\
\hline T. F. & 67 & ITAC & T1N0 & Nem \\
\hline K. J. & 70 & SNUC & T3N0 & Nem \\
\hline M. J. & 59 & Laphámcarcinoma & T4N0 & $\begin{array}{l}\text { Definitív } \\
\text { kemoirradiáció }\end{array}$ \\
\hline P. I. & 61 & ENB & Kadish C & Nem \\
\hline
\end{tabular}

ENB = esthesioneuroblastoma; ITAC $=$ intestinalis típusú adenocarcinoma; SNUC = sinonasalis nem differenciált carcinoma 

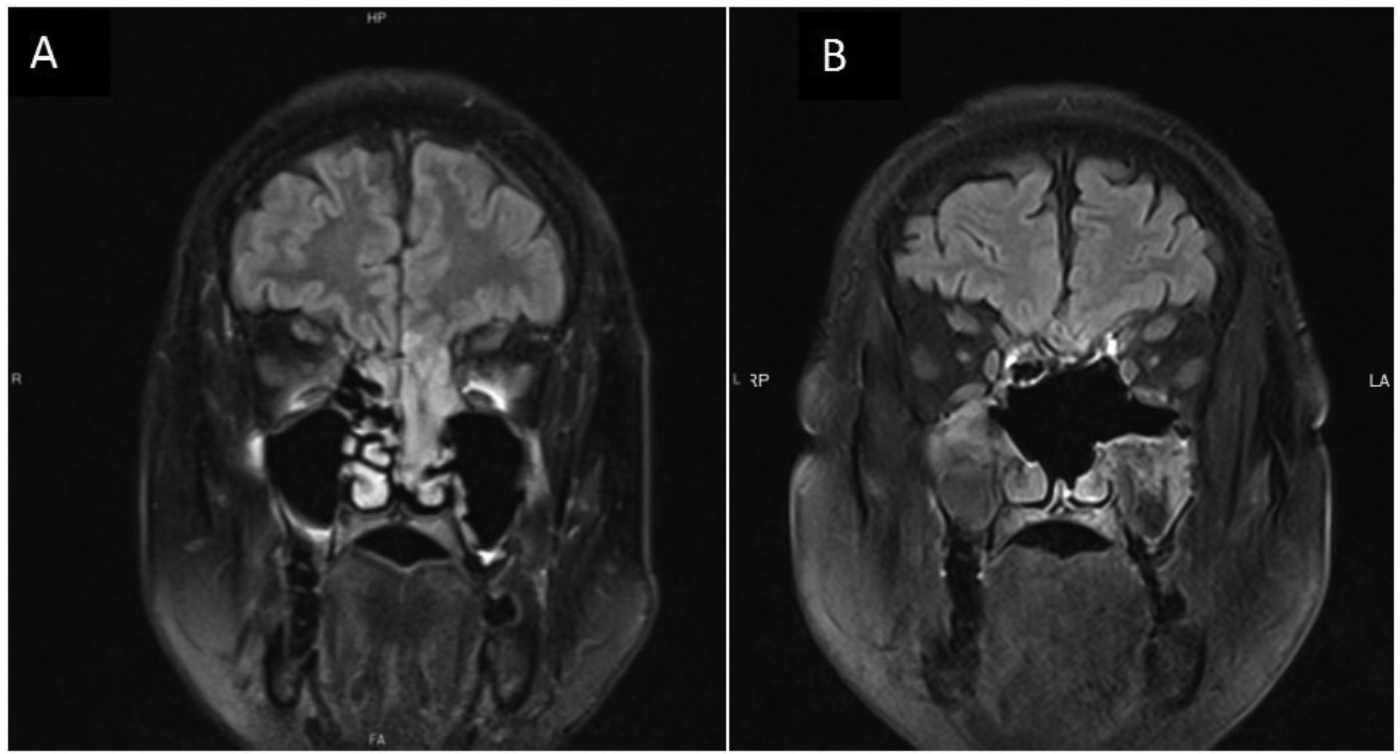

1. ábra

A lamina cribrosát is destruáló esthesioneuroblastoma MR-felvétele (A). A három hónappal a tumorreszekció után készült posztoperatív MR-felvétel (B)

$\mathrm{MR}=$ mágneses rezonancia

nem differenciált carcinoma, l esetben intestinalis típusú adenocarcinoma, illetve 1 esetben laphámcarcinoma képezte (1.ábra).

\section{A mütét menete}

A műtét első lépése az orrnyálkahártya kellő mértékű lohasztása, mely minden rinológiai beavatkozás elengedhetetlen feltétele. Erre a célra gyakorlatunkban kiválóan megfelel a fenilefrin és a lidokain keveréke $(0,10 \mathrm{~g}$ phenylephrinium chloratum, 5,00 g lidocainum chloratum $100 \mathrm{~g}$ solvens viscosában), mely vattatampon segítségével juttatható az orrüregekbe legalább 10 percig alkalmazva. Ezalatt a lemosás, izolálás és egyéb műtéti előkészületek, valamint a navigációs eszköz beállítása is elvégezhető. Rövid kitérőként fontos megemlíteni, hogy ezt a számtalan kritikus struktúrával bonyolított anatómiai környezetben végzett beavatkozást ajánlatos navigációs rendszer asszisztenciája mellett kivitelezni. A beteg fektetése az endoszkópos rinológiai beavatkozásoknál is megszokott 15-20 fokban emelt és minimálisan jobbra fordított fejhelyzettel történjen, illetve törzsből is flektálható kissé a mútőasztal. Az idegsebészeti műtőkben általános a Mayfield-típusú fejrögzítő alkalmazása. Fejrögzítés esetén, ha a mütőszemélyzet még nem rendelkezik kellő endoszkópos tapasztalattal, a fül-orr-gégész mindig ellenőrizze, hogy a fejet megfelelő helyzetben fixálták-e, hiszen az idegsebészeti beavatkozásokhoz általában más pozícióban fektetik a beteget. Az operáció sikeréhez szinte elengedhetetlen navigációs rendszer használata, melynek körültekintő, a lehető legpontosabb kalibrációja szintén a mütétet megelőző lépés. Az ép szövetekben történő tumorreszekció, a pontos műtéti pozíció, valamint az életfontosságú képletek helyzete a navigáció birtokában bármikor ellenőrizhető. Az operáció lépéseinek pontos sorrendjére befolyással lehet a tumor mérete és kiterjedése is, általánosságban azonban elmondható, hogy térnyerés szempontjából ajánlatos a beavatkozást az orrsövény cranialis harmadának-felének eltávolításával kezdeni. Ez a lépés elkerülhető, ha a daganat és az azt övező biztonsági zóna sem érinti az orrsövényt, bár a lamina cribrosát destruáló folyamatok esetében erre nem számíthatunk. Az ethmoid tető laterális részét érintő daganatnál, illetve a középső vagy hátsó skála feltárásainak során azonban megkímélhető az orrsövény. Amennyiben a daganat kiterjedése nem korlátozza jelentősen a tájékozódást, a következő lépés a reszekció elülső határának kidolgozása lesz, melynek érdekében egy Draf szerinti III-as típusú homloküreg-feltárást szükséges kivitelezni [13]. Ez a technikailag kissé körülményes feltárás a homloküregek szájadékának felkeresését, majd azok olyan mértékü - jelentős csontmunkával járó - tágítását jelenti, melynek eredményeképpen a két orbita medialis határa között a homloküreg teljes alsó fala elvételre kerül. Ekkor rendkívül jó rálátás nyílik a fossa olfactoria elülső aspektusára. A tumorreszekció határait bizonyos fokig a daganat kiterjedése határozza meg. Amennyiben a folyamat a laterális orrfalat roncsolja, úgy akár az orrfenékig elvételre kerülhetnek a struktúrák, ha azonban csak a fossa olfactoria és a rostasejtek területe érintett, akkor az alsó orrkagylók még megtarthatók. A laterális orrfalon, az anterior határt általában a ductus nasolacrimalis felett rendszerint jól kivehető csontléc, a linea maxillaris jelzi. A reszekció hátsó határa a sinus sphenoidalis mellső fala által meghatározott sík. A koponyaalapon az orbitatető jelenti a laterális határt, az orrüreg szintjében azonban a lamina papyraceát áttörő daganatok az orbitába is követhetők, amennyiben az 


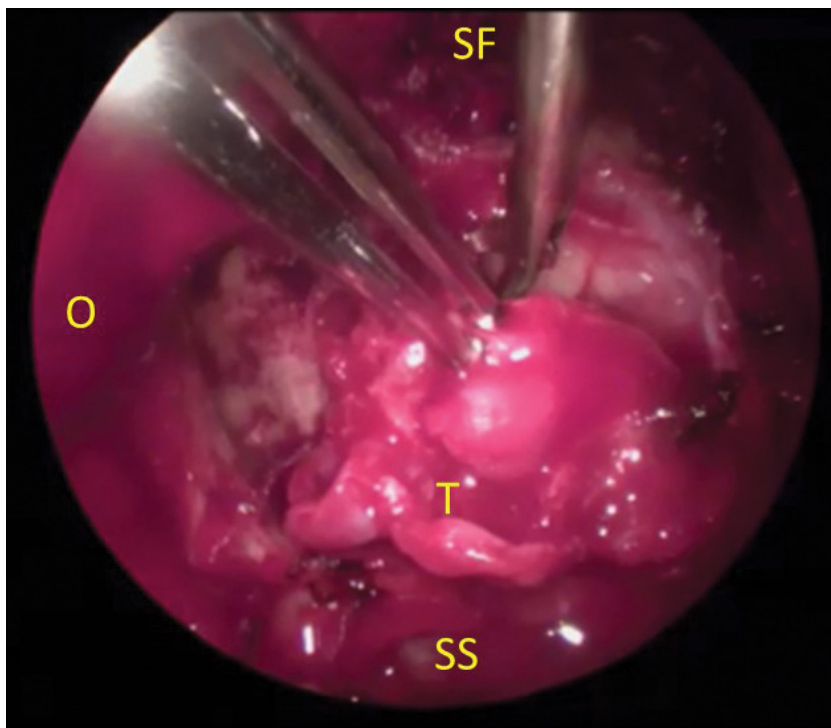

2. ábra

A kemény agyburok reszekciója endoszkópos intraoperatív felvételen, alatta a daganat koponyaalapot destruáló részlete

$\mathrm{SF}=$ sinus frontalis; $\mathrm{O}=$ orbita $; \mathrm{T}=$ tumor $; \mathrm{SS}=$ sinus sphenoi dalis

orbitalis zsírt még nem érinti a folyamat. Fontos megjegyezni, hogy a mütét bármelyik fázisában szükség lehet a tumorszövet megkisebbítésére, részleteinek eltávolítására, hiszen bizonyos esetekben mind a tájékozódást, mind a manipulációt lehetetlenné teheti egy nagy kiterjedésú daganat. Ez az eljárás a klasszikus onkológiai sebészeti szemléletmóddal látszólag szembemegy, végső soron azonban a sebészi széleket nem befolyásolja ez a lépés. Az orr üregébe lógó daganattömeg exophyt részét több részletben eltávolítva, végül a tumor kiindulópontja tisztán kivehetôvé válik, így az biztonsági zónával együtt reszekálható. Az irodalom a „piecemeal resection” terminus technicust alkalmazza erre az eljárásra. Ahogy az ethmoid sejtek, a középső kagyló és a laterális orrfal nyálkahártyája a tumorszövettel egyetemben már csak a koponyaalapon tapad, a kialakított szabad csontfelszínen elkezdhető a koponyaalap reszekciós határainak kidolgozása. Ekkor szükséges elvégezni az arteria ethmoidalis anterior és posterior felkeresését, csontborítékának lefejtését és az erek ligatióját elektromos eszközzel vagy klippel. Ezek után fúróval és Kerrison-rongeurrel a fossa olfactoriát körbevágjuk. Vegyes megítélés alá esik a durát elérő daganatok esetében az agyburok reszekciójának kérdése. Egyes szerzők ilyen esetekben is eltávolítják a daganattal érintkező duraterületet, míg más vélemények szerint az agyburok ellenálló barrierként viselkedik, melyet a daganat ritkán infiltrál [14]. Ebben az esetben jelentős morbiditást spórolhatunk meg a durareszekció elkerülésével, kiváltképp, ha később posztoperatív sugárkezelésre is sor kerül. Durakimetszés nélkül a daganat tompán leválasztható az agyburokról a crista gallival egyetemben. Amennyiben a dura is reszekcióra kerül, rendkívül óvatos manipulációval, a leghelyesebben mik-

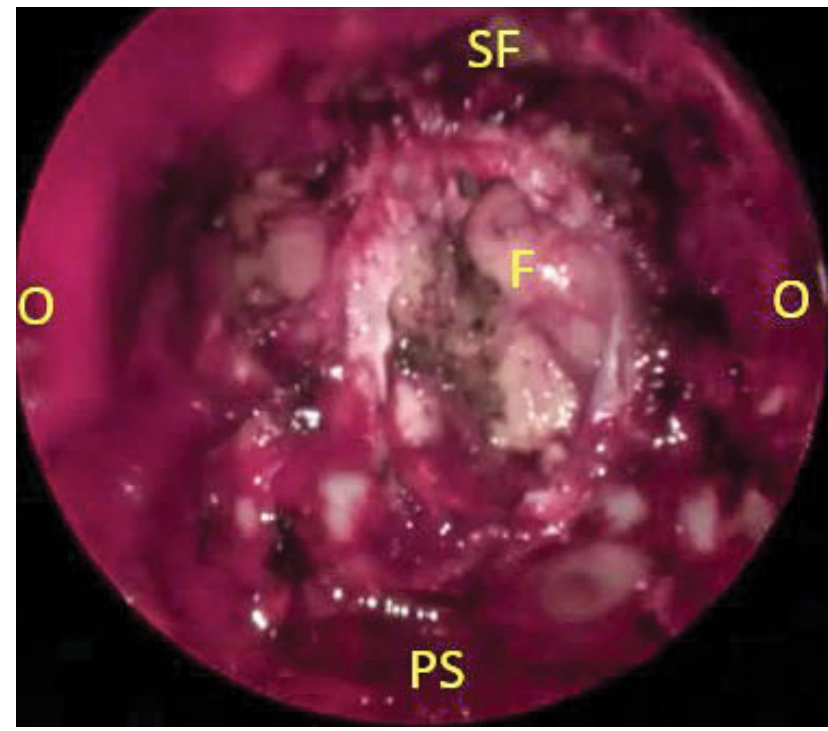

3. ábra

A transcribriform reszekció utáni állapot endoszkópos intraope ratív felvételen

$\mathrm{SF}=$ sinus frontalis $; \mathrm{O}=$ orbita $; \mathrm{PS}=$ planum sphenoidale $; \mathrm{F}=$ frontális gyrusok

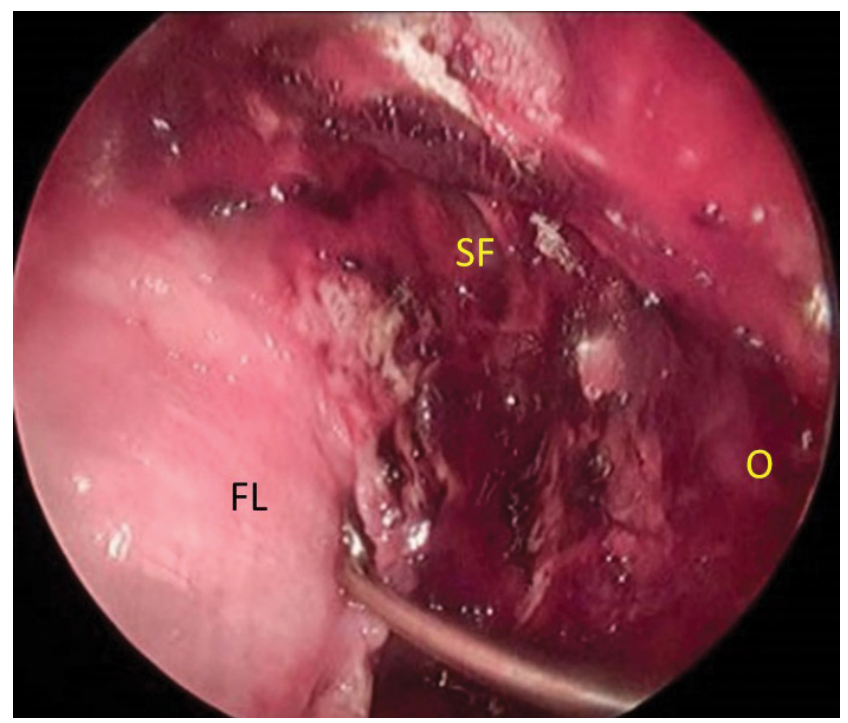

4. ábra

A koponyaalap rekonstrukciójának intracranialis-extraduralis rétegét képező fascia lata lemez behelyezése, a reszekció során létrejött csontperem és a dura mater közé

$\mathrm{SF}=$ sinus frontalis; $\mathrm{O}=$ orbita $; \mathrm{FL}=$ fascia lata graft

roolló segítségével vágható körbe a kérdéses terület (2. és 3. ábra). Eközben azt is figyelembe kell venni, hogy a középvonalban a két frontalis lebeny között a dura két rétegben, cranialisan a két frontális lebeny közé fut. A koponyaalap-mútétek kulcskérdése a tumor eltávolítását követő rekonstrukció, különösen a durakimetszéssel járó esetekben. A koponyaalap vízzáró, stabil helyreállítása nem nélkülözhető, a mútét befejezésekor liquorszivárgás nem maradhat fenn. Ennek érdekében munkacsoportunk a háromrétegü, saját fascia lata felhasználásával végzett eljárást alkalmazza. Az agyszövet felől haladva az 
első vonal a durán látható reszekciós szél és az agyszövet közé „underlaid” behelyezett intraduralis réteg, majd a csontszélek és a dura közé helyezett intracranialis-extraduralis réteg képezi a második vonalat (4. ábra). Mindez alá, már extracranialisan kerül az utolsó réteg, mely végül szabad orrnyálkahártya- vagy nasoseptalis érnyeles lebennyel is fedhető. Az utóbbi autograftokat azonban malignus folyamatok esetén a tumor általában infiltrálja, így azok áldozatul esnek a reszekciónak. Minden réteg közé helyezhető térkiegyenlítő jelleggel saját hasi zsír [14, 15]. Szövetragasztót a rétegek közé nem célszerú használni, mert tapasztalatunk szerint a várttal ellentétben inkább eltávolítja a rétegeket egymástól, és a ragasztó felszívódása után azok már nem tudnak megfelelően összeragadni. Ezen anyagok használata azonban a rekonstrukció felületét bevonva jó hatású a korai posztoperatív időszakban. A mútét végeztével a rekonstrukciót orrtamponálással célszerú alátámasztani. Lebomló, szilárd orrüregi tamponok (például PosiSep - Hemostasis, LLC, Saint Paul, MN, Amerikai Egyesült Államok [USA] vagy NasoPore - Stryker, Kalamazoo, MI, USA) alkalmazása látszik a legelőnyösebbnek, hiszen az eltávolítandó tamponok kihúzásakor félő, hogy a rekonstrukció is elmozdul. A beteg a mútét utáni napját idegsebészeti betegek ellátásában járatos intenzív terápiás osztályon tölti.

A betegek utánkövetése az első évben havonta végzett orrendoszkópos kontrollvizsgálattal és félévenként MRellenőrzéssel történik. A második évtől évenként zajlik a képalkotó vizsgálatokkal végzett ellenőrzés, és 3 havonta szükséges endoszkópos vizsgálattal ellenőrizni a mütéti területet. Hosszú távon, a harmadik évtől élethosszig tartó, fél-egy éves rendszerességgel végzett követést alkalmazunk.

\section{Eredmények}

A betegek követési ideje 14 és 46 hónap között alakult, átlagosan 22,8 hónap volt. A mütét indikációját 2 esetben a Kadish szerinti C-stádiumú esthesioneuroblastoma, l esetben T3N0 sinonasalis nem differenciált carcinoma, l esetben TIN0 intestinalis típusú adenocarcinoma, illetve további 1 esetben T4N0-laphámcarcinoma képezte. A mütétek során intraoperatív szövődmény nem lépett fel. A reszekátumok és a biztonsági utánmet- szések szövettani feldolgozása során 1 betegnél a sebészi szél tumoros érintettsége nyert igazolást. A posztoperatív időszakban egy beteg esetében liquorrhoea, illetve pneumocephalus alakult ki, mely „lumbar drain” (lumbalis drenázs) alkalmazása és konzervatív kezelés mellett rendeződött. Három betegünk esetében az idegsebészeti „onkoteam” állásfoglalása alapján posztoperatív sugárkezelés mellett döntöttünk, melyet 1 beteg visszautasított. Nem részesült posztoperatív onkológiai kezelésben még további 2 betegünk. Egyikük esetében a daganat kis kiterjedése miatt (T1N0), a másik esetben pedig a már lezajlott neoadjuváns, teljes dózisú radiokemoterápia miatt tekintettünk el a posztoperatív onkológiai kezeléstôl. Az utánkövetés során egyik beteg esetében sem észleltünk recidívát sem a képalkotó felvételeken, sem pedig az endoszkópos ellenőrzés során (2. táblázat). Egy beteg cardiovascularis alapbetegsége következményeként a mütét után 21 hónappal exitált.

\section{Megbeszélés}

A sinonasalis régióban jó- és rosszindulatú daganatok egyaránt előfordulhatnak. Fontos hangsúlyozni, hogy az ebben a régióban megjelenő malignus daganatok igen ritkák, ráadásul szövettani jellemzőiket tekintve is igen nagy változatosságot mutatnak. Az orr és orrmelléküregek területén előforduló benignus daganatok mellett kifejlődhet laphám- és adenocarcinoma, neuroendokrin tumor, lymphoma és esthesioneuroblastoma, valamint ritkábban melanoma malignum, sarcoma vagy nem differenciált daganat is [14-20]. Miután az említett malignus folyamatok csaknem mindegyike különböző kezelési stratégiát tesz szükségessé, érthető, hogy egy-egy daganat esetében még a legnagyobb tapasztalattal bíró centrumok sem rendelkeznek magasabb esetszámmal. Ez abban az esetben fokozottan érvényes, ha a daganat a koponyaalapot is érinti, illetve azon áttör, hiszen ekkor már speciális mútéti technika szükséges ahhoz, hogy a daganat eltávolítása maradéktalanul megtörténhessen. Hazánkban az eddigi gyakorlat sajnos e kiterjedt, az orrüreg határait átlépő daganatok esetében az onkológiai kezelést részesítette előnyben, pedig a korszerü elveknek megfelelően - különösen a laphám- és adenocarcinomák, valamint az esthesioneuroblastoma esetén - a kezelés első vonala a sebészi reszekció $[3,5]$. A mütéti megoldás

2. táblázat | Transcribriform koponyaalap-reszekción átesett betegeink adatai a mútét részleteit és a követési időt feltüntetve

\begin{tabular}{|c|c|c|c|c|c|c|}
\hline Beteg & Reszekciós szélek & Rekonstrukció & Szövődmény & Posztoperatív kezelés & Recidíva/residuum & Követés (hó) \\
\hline Sz. S. & Negatív & 3 réteg fascia lata & Nincs & Nem vállalta & Nincs & 46 \\
\hline T. F. & Negatív & 3 réteg fascia lata & Nincs & Nem & Nincs & 33 \\
\hline K. J. & Negatív & 3 réteg fascia lata & Nincs & 66 Gy fotonbesugárzás & Nincs & 21 \\
\hline M. J. & Negatív & 3 réteg fascia lata & Liquorrhoea, PC & Nem & Nincs & 17 \\
\hline P. I. & Érintett & 3 réteg fascia lata & Nincs & 66 Gy fotonbesugárzás & Nincs & 14 \\
\hline
\end{tabular}

Gy = gray; PC $=$ pneumocephalus 
lehetôleg a legkisebb invazivitással, de teljes ablasticitassal járjon. A megfelelően felszerelt, HD vagy $4 \mathrm{~K}$ endoszkópos toronnyal és navigációs rendszerrel, esetleg intraoperatív CT készítésének lehetőségével bíró mütő és az endoszkópos sebészetben jártas operatőrök segítségével az orbita vagy az agyburok, sőt bizonyos mértékig az agyszövet érintettségével járó esetek is uralhatók endoszkópos, minimálisan invazív úton. Nem minden esetben végezhető azonban teljesen endoszkópos mútét. A külső feltárás nem kerülhető el, ha a tumor érinti az arc bőrét, az arcüreg mellső, alsó vagy laterális falát, a homloküreget, illetve az orbita lágyszöveteit, vagy a daganat nagyobb tömege intracranialisan helyezkedik el. Ilyenkor kombinált mútét végzendő, melynek során a külső feltárás ellenére is kap szerepet az endoszkóp és az operációs mikroszkóp a minél pontosabb vizualizáció céljából. Az idegsebész és a fül-orr-gégész hatékony együttmúködése a diagnózis felállítása, a mútét és az utókezelés során is egyaránt elengedhetetlen az eredményes kezelés eléréséhez. Az endoszkópos technika, mint minden minimálisan invazív mütéti megoldás, számtalan előnnyel jár. Az arcon keresztül végzett beavatkozásokhoz képest a kiterjedt külső feltárás elkerülése a legegyértelmúbb előnye az új technikának, így a betegeket nem fenyegeti az esetenként hátrányos kozmetikai eredménnyel gyógyuló, az arc középső harmadát torzító seb. A kisebb invazivitás mútét utáni gyorsabb gyógyulást és kisebb morbiditást eredményez, az endoszkópos technika bevezetésekor azonban a legtöbb kritika az ablasticitas, valamint a stabil, vízzáró koponyaalap-rekonstrukció okán érte az új megoldást. Az irodalmi adatok alapján ennek ellenére ma már valószínúsíthető, hogy a külső feltárással végzett műtét semmilyen szempontból sem múlja fölül az endoszkópos megoldást. Fu és mtsai összesen 36 közlemény adatait dolgozták fel 609 beteg adatai alapján készített metaanalízisükben. Közleményük rámutat, hogy az esthesioneuroblastomás esetek kapcsán nincs különbség a lokoregionális tumorkontroll és a metasztázis nélküli túlélési idő szempontjából a külső feltárásból, illetve az endoszkópos úton végzett beavatkozások között. Ezenfelül az endoszkópos mútétek eredményeképpen minden betegcsoport esetében szignifikánsan hoszszabb teljes és betegségmentes túlélés adódott [21]. Gallia és mtsai esthesioneuroblastomás betegeiknél minden beavatkozásuk során ép sebészi szélekkel tudtak endoszkópos transcribriform reszekciót végezni [22]. Nation és mtsai gyermekgyógyászati beteganyagon végzett endoszkópos koponyaalap-beavatkozások eredményeit ismertető közleményük szerint egyetlen esetben sem tapasztaltak posztoperatív liquorrhoeát [23].

A koponyaalap-reszekciók során természetesen számos szövődménnyel kell számolnia az operatőrnek. Ezek a műtét alatt és a posztoperatív időszakban egyaránt felléphetnek. Intraoperatív szövődményként jelentkezhet vérzés, az orbita képleteinek és az agyidegeknek a sérülé- se. Megjegyzendő, hogy az ebben a lokalizációban észlelt tumorok esetén a beteg már nem rendelkezik szaglással a mütét idején, így a reszekció során eltávolított bulbus nervi olfactorii nem tekinthető szövődménynek. A mütét utáni időszak szövődményei a nasalis liquorrhoea, a meningitis, vérzések, illetve a hypophysis elégtelensége [24, 25]. Hangsúlyozandó, hogy ezen szövődmények lehetősége fennáll a külső feltárással végzett koponyaalap-mútéteknél is, tetézve az arc feltárásának lehetséges sebgyógyulási zavaraival. Munkacsoportunk megfigyelte továbbá, hogy a külső feltárással végzett craniofacialis feltáráson átesett betegeink között két alkalommal is súlyos ostitis alakult ki a frontális oszteoplasztikus lebenyben, évekkel a beavatkozás után. A szuppuráló csontfolyamat miatt mindkét esetben a csontlemezek mưtéti eltávolítására kényszerültünk.

\section{Következtetés}

Munkacsoportunk öt betegen végzett transcribriform feltárással mútétet, melyek során esthesioneuroblastoma, nem differenciált sinonasalis carcinoma, intestinalis típusú adenocarcinoma és laphámcarcinoma eltávolítására került sor. Betegeinknél minden esetben sikerült a daganattömeget makroszkóposan eltávolítani, és bár a sebészi széleket ezeknél a beavatkozásoknál nehéz értékelni, a küldött biztonsági utánmetszések 4 esetben tumormentesnek bizonyultak. Intraoperatív szövődmény nem lépett fel. A posztoperatív időszakban egy betegünknél liquorrhoea jelentkezett, illetve ezzel párhuzamosan nagyobb kiterjedésű pneumocephalus alakult ki. A szövődményt lumbalis drenázs alkalmazásával hárítottuk el. A betegeket az onkológiai sebészetben megszokott szoros utánkövetéssel ellenőriztük. A követés során residualis tumort vagy recidívát egyik betegünknél sem észleltünk. Az elülső koponyaalap rosszindulatú daganatainak sebészi megoldásaként az endoszkópos, transnasalis, transcribriform feltárással végzett reszekció kiváló alternatívája a külső feltárásból végzett mütéteknek a biztonságos kivitelezhetőség és a megfelelő onkológiai eredmény elérésének szempontjából is.

Anyagi támogatás: A közlemény megírása, illetve a kapcsolódó kutatómunka anyagi támogatásban nem részesült.

Szerzői munkamegosztás: P. Z.: A közlemény szerzője, a mútétek operatőre. B. A.: A mútétek operatőre. G. I.: Az eredmények feldolgozása, értelmezése. T. I., N. N.: Irodalmi áttekintés. L. L.: Vizsgálatvezető, a mútétek operatőre. A cikk végleges változatát valamennyi szerző elolvasta és jóváhagyta.

Érdekeltségek: A szerzőknek nincsenek érdekeltségeik. 


\section{Irodalom}

[1] Farina D, Borghesi A, Botturi E, et al. Treatment monitoring of paranasal sinus tumors by magnetic resonance imaging. Cancer Imaging 2010; 10: 183-193.

[2] Van Buren JM, Ommaya AK, Ketcham AS. Ten years' experience with radical combined craniofacial resection of malignant tumors of the paranasal sinuses. J Neurosurg. 1968; 28: 341-350.

[3] Snyderman CH, Carrau RL, Kassam AB, et al. Endoscopic skul base surgery: principles of endonasal oncological surgery. J Surg Oncol. 2008; 97: 658-664.

[4] Stammberger H, Posawetz W. Functional endoscopic sinus surgery. Concept, indications and results of the Messerklinger technique. Eur Arch Otorhinolaryngol. 1990; 247: 63-76.

[5] Choi D, Subramanian A, Elwell V, et al. Endoscopic transnasal surgery as a replacement for maxillotomy techniques to approach the central skull base: fewer complications and more acceptable to patients? Neurol Surg B 2014; 75: 165-170.

[6] Ishii Y, Tahara S, Teramoto A, et al. Endoscopic endonasal skull base surgery: advantages, limitations, and our techniques to overcome cerebrospinal fluid leakage: technical note. Neurol Med Chir. 2014; 54: 983-990.

[7] Wagenmann M, Schipper J. The transnasal approach to the skul base. From sinus surgery to skull base surgery. GMS Curr Top Otorhinolaryngol Head Neck Surg. 2011; 10: 160-165.

[8] Jeon C, Hong CK, Woo KI, et al. Endoscopic transorbital sur gery for Meckel's cave and middle cranial fossa tumors: surgical technique and early results. J Neurosurg. 2018 Nov 1. doi: 10.3171/2018.6.JNS181099. [Epub ahead of print]

[9] Fülöp B, Bella Z, Palágyi P, et al. Endoscopic removal of tuberculum sellae meningeoma through endonasal transsphenoidal approach. [Tuberculum sellae meningeoma endoszkópos eltávolítása endonasalis transsphenoidalis feltárásból.] Ideggyogy Szle. 2016; 69: 133-138. [Hungarian]

[10] Shkarubo AN, Koval KV, Chernov IV, et al. Endoscopic endonasal transclival approach to tumors of the clivus and anterior region of the posterior cranial fossa (results of surgical treatment of 136 patients). World Neurosurg. 2019; 121: e246-e261.

[11] Radulesco T, Penicaud M, Dessi P, et al. Endoscopic surgery for sinonasal tumors: the transcribriform approach. J Stomatol Oral Maxillofac Surg. 2017; 118: 248-250.

[12] Majmundar N, Kamal NH, Reddy RK, et al. Limitations of the endoscopic endonasal transcribriform approach. J Neurosurg Sci. 2018 ; 62: 287-296.
[13] Carney AS. Draf III frontal sinus surgery: "How I do it." Am J Rhinol Allergy 2017; 31: 338-340.

[14] Yokoi H, Kodama S, Kogashiwa Y, et al. An endoscopic endonasal approach for early-stage olfactory neuroblastoma: an evaluation of 2 cases with minireview of literature. Case Rep Otolaryngol. 2015; 2015: 541026 .

[15] Kassam A, Carrau RL, Snyderman CH, et al. Evolution of reconstructive techniques following endoscopic expanded endonasal approaches. Neurosurg Focus 2005; 19: E8.

[16] Lepera D, Volpi L, Facco C, et al. Endoscopic treatment of Ewing sarcoma of the sinonasal tract. J Craniofac Surg. 2016; 27: 1001-1006.

[17] Antognoni P, Turri-Zanoni M, Gottardo S, et al. Endoscopic resection followed by adjuvant radiotherapy for sinonasal intestinal-type adenocarcinoma: retrospective analysis of 30 consecutive patients. Head Neck 2015; 37: 677-684.

[18] Klironomos G, Gonen L, Au K, et al. Endoscopic management of esthesioneuroblastoma: our experience and review of the literature. J Clin Neurosci. 2018; 58: 117-123.

[19] Lepera D, Leone F, Volpi L, et al. Endoscopic endonasal approach for sinonasal and anterior skull base malignancies in the elderly. Head Neck 2018; 40: 917-926.

[20] Liu JK, Eloy JA. Expanded endoscopic endonasal transcribriform approach for resection of anterior skull base olfactory schwannoma. J Neurosurg. 2012; 32(Suppl): E3.

[21] Fu TS, Monteiro E, Muhanna N, et al. Comparison of outcomes for open versus endoscopic approaches for olfactory neuroblastoma: a systematic review and individual participant data metaanalysis. Head Neck 2016; 38(Suppl 1): E2306-E2316.

[22] Gallia GL, Reh DD, Lane AP, et al. Endoscopic resection of esthesioneuroblastoma. J Clin Neurosci. 2012; 19: 1478-1482.

[23] Nation J, Schupper AJ, Deconde A, et al. Pediatric endoscopic endonasal approaches for skull base lesions in the very young: Is it safe and effective? J Neurol Surg B Skull Base 2018; 79: 574579.

[24] Deschler DG, Gutin PH, Mamelak AN, et al. Complications of anterior skull base surgery. Skull base Surg. 1996; 6: 113-118.

[25] Constantinidis J, Konstantinidis I. Avoiding complications in endoscopic skull base surgery. Curr Opin Otolaryngol Head Neck Surg. 2017; 25: 79-85.

(Piski Zalán dr., Pécs, Munkácsy M. u. 2., 7621 e-mail: zpiski@gmail.com)

\section{„Gutta cavat lapidem." (Ovidius) (A vízcsepp kivájja a követ.)}

A cikk a Creative Commons Attribution 4.0 International License (https://creativecommons.org/licenses/by/4.0/) feltételei szerint publikált Open Access közlemény, melynek szellemében a cikk bármilyen médiumban szabadon felhasználható, megosztható és újraközölhető, feltéve, hogy az eredeti szerző és a közlés helye, illetve a CC License linkje és az esetlegesen végrehajtott módositások feltüntetésre kerülnek. (SID_1) 